\title{
Organic carbon transport from the Southern Ocean and bacterial growth in the Antarctic Intermediate Water masses of the Tasman Sea
}

\author{
D. J. W. Moriarty ${ }^{1, *}$, M. J. O'Donohue ${ }^{2}$ \\ ${ }^{1}$ CSIRO Division of Fisheries, PO Box 120, Cleveland, Queensland 4163, Australia \\ ${ }^{2}$ Department of Botany, University of Queensland, Queensland 4072, Australia
}

\begin{abstract}
The concept that organic carbon is transported to the equatorial region at intermediate water depths from subantarctic frontal zones has been re-investigated using the tritiated thymidine method to determine rates of bacterial DNA synthesis in water masses of the Tasman Sea. There was a higher bacterial growth rate and thus a higher flux of organic carbon through bacteria in the Antarctic Intermediate Water ( 900 to $1000 \mathrm{~m}$ depth) than in the water masses immediately above or below in the Tasman Sea east and south of Tasmania. Values for bacterial production were 4 to $8 \mu \mathrm{g} \mathrm{C} \mathrm{m} \mathrm{m}^{-3} \mathrm{~d}^{-1}$, which are equivalent to a consumption of about 3 to $6 \mu \mathrm{O} \mathrm{O}_{2} \mathrm{~L}^{-1} \mathrm{yr}^{-1}$ In the deeper layer at 1200 to $1500 \mathrm{~m}$, rates were 3 to 4 times lower. These rates are compatible with other data on oxygen utilisation. Our results support the concept that organic matter sinks with downwelling water in the zone between the Subtropical Convergence and the Polar Front in the Southern Ocean and is advected towards the equator below the photic zone.
\end{abstract}

KEY WORDS: Oceanic carbon cycling $\cdot$ Southern Ocean $\cdot$ Pacific Ocean $\cdot$ Bacteria

\section{INTRODUCTION}

In most conceptual models of oceanic carbon cycling, a high proportion of organic carbon mineralisation to $\mathrm{CO}_{2}$ is shown to occur in the upper mixed layer and usually less than $10 \%$ of the organic matter sinks to the deep ocean (e.g. Suess 1980). The organic matter that sinks to the deep ocean and its subsequent mineralisation to $\mathrm{CO}_{2}$ maintains a high concentration of $\mathrm{CO}_{2}$ that is oversaturated compared to surface waters in equilibrium with the atmosphere. The concept of a 'biological pump' has been used to describe the processes by which organic matter is transferred to the deep ocean; it is complex and there are at least 3 different processes leading to sedimentation (Longhurst 1991). The proportion of organic carbon that is recycled in the water column can vary considerably, and is influenced

- Present address: ARDA-Tek, 315 Main Road Wellington Point, Queensland 4160, Australia by many factors such as the species composition of phytoplankton, diel migration of zooplankton, and sources of nitrogen. The vertically sinking organic matter is thought to be the main source of organic matter for bacterial activity in intermediate and deepocean water masses (Cho \& Azam 1988, Karl 1988).

A different concept, proposed by Sorokin over 20 yr ago from studies in the central Pacific Ocean, is that significant amounts of organic carbon were transported at intermediate water depths from subantarctic frontal zones (Sorokin 1971, 1977, 1978, Sorokin et al. 1985). His ideas have not been accepted, because the methods he used to quantify bacterial production, and thus carbon flux and oxygen utilisation, gave values that were too high to be compatible with other data on rates of oxygen utilisation (Banse 1974, Packard 1985).

Sorokin (1971, 1973) and Sorokin et al. (1985) observed a band of high microbial productivity and animal biomass in a layer of water lying 'at the upper boundary of the Intermediate Antarctic waters' in the Pacific and Indian Oceans. In the Pacific at the equator, 
the water mass with high bacterial activity was warmer and shallower than at southern latitudes. Sorokin found that this layer contained a stock of labile organic matter that was only slowly mineralised in situ because the temperature was too low for maximum activity of the bacteria. Sorokin's values for microbial production in the central Pacific were $700 \mu \mathrm{g} \mathrm{C} \mathrm{m}^{-3} \mathrm{~d}^{-1}$ and in the Indian Ocean of 70 to $300 \mu \mathrm{g} \mathrm{C} \mathrm{m}^{-3} \mathrm{~d}^{-1}$. These values are equivalent to about 100 to $430 \mathrm{ml} \mathrm{O}_{2} \mathrm{~m}^{-3} \mathrm{yr}^{-1}$, which are very high and have been questioned (Banse 1974).

If the only source of organic matter for the bacteria in the deep ocean were particles sinking from the upper mixed layer, then bacterial growth should decrease continuously with depth as found by Cho \& Azam (1988). If Sorokin's hypothesis were correct, however, then rates of bacterial growth rates and production in the Antarctic Intermediate Water (AAIW) or in mode waters should be greater than in overlying water masses. We have reinvestigated Sorokin's hypothesis in waters southeast of Australia, using modern techniques for quantifying bacterial growth rates.

\section{MATERIALS AND METHODS}

Water was collected east of the continental margin of Tasmania in July 1991 and south of the margin in February 1992 in water columns ranging from the surface through the AAIW (Fig. 1). The AAIW in the Tasman Sea has varying properties, due to mixing of water from different sources, and for the experiments reported here, the core was characterised by the salinity minimum and a temperature of 4 to $6^{\circ} \mathrm{C}$ (Tomczak \& Godfrey 1994)

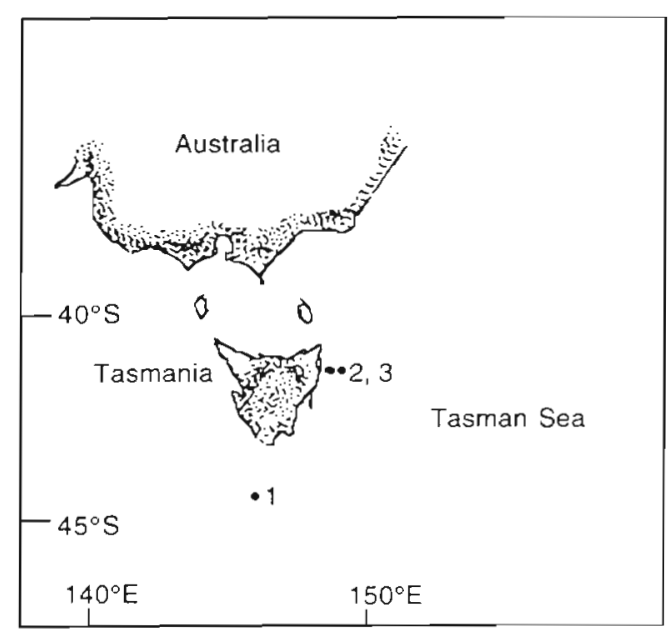

Fig. 1. Southeastern Australia, showing location of Stns 1, 2 and 3 off the coast of Tasmania. Exact locations are given in subsequent figure legends
Water was collected with Niskin bottles on a rosette sampler with sensors for conductivity, temperature and depth. Water was siphoned from the Niskin bottles with $13 \mathrm{~cm}$ diameter tubing to minimise disruption of bacteria on particles. Preliminary samples of water from various depths were incubated with different concentrations of tritiated thymidine and for differing periods of time to determine the optimum conditions for measuring rates of DNA synthesis (Moriarty 1990). A concentration of $10 \mathrm{nM}$ was used, as it was found to give no apparent dilution of radioisotope (Moriarty 1990). Four replicate subsamples of $50 \mathrm{ml}$ from each depth down to $900 \mathrm{~m}$, and $100 \mathrm{ml}$ samples below $1000 \mathrm{~m}$, were incubated with $10 \mathrm{nM}$ thymidine for $12 \mathrm{~h}$ $(0$ to $200 \mathrm{~m}), 25 \mathrm{~h}(400$ to $1000 \mathrm{~m})$ or $30 \mathrm{~h}(1100$ to $1200 \mathrm{~m}$ ) at in situ temperature. Bacterial productivity was calculated from growth rates (Moriarty 1990). Bacterial productivity is a measure of carbon flux through the bacteria; it could be at least equivalent to and up to 3 times the productivity, depending upon the growth efficiency and whether there was recycling within the water mass (Moriarty 1989). Labelled DNA was hydrolysed and counted separately from other macromolecules on the filters, which were also counted to determine the proportion of tritium incorporated into DNA compared to that incorporated into total macromolecules (Moriarty 1990).

At some stations, the growth of free bacteria was compared to that of particle-bound bacteria by using $2 \mu \mathrm{m}$ pore size filters to separate them from the total bacterial community, which was collected on $0.2 \mu \mathrm{m}$ filters after incubation with tritiated thymidine.

A conversion factor of $1 \times 10^{18}$ cells produced $\mathrm{mol}^{-1}$ thymidine incorporated into DNA was used to calculate growth rates; the range of uncertainty with this factor is mostly 2-fold (Riemann et al. 1987, Moriarty 1988). The average cell volume of the bacteria in all waters was determined by microscopy to be $0.05 \mu^{3}$; a carbon content of $20 \mathrm{fg} \mathrm{cell}^{-1}$ was used in calculations (Lee \& Fuhrman 1987). The precision of the results was mostly better than $\pm 10 \%$ of the mean; a 1 -way analysis of variance (ANOVA) and Least Significant Difference analysis was used to test differences between means.

\section{RESULTS}

Bacterial productivity was generally an order of magnitude or more lower in the water masses of the thermocline at 400 to $600 \mathrm{~m}$ depth than in the upper mixed layer (Figs, 2, 3 \& 4). As predicted from Sorokin's earlier work, however, bacterial productivity in portions of the AAIW was greater than in water masses at 400 to $600 \mathrm{~m}$ depth at 2 of the stations (Figs. 2 
\& 3). At Stn 3, the bottom depth was only $1225 \mathrm{~m}$ and the deepest sample was at $1150 \mathrm{~m}$; at this station, bacterial productivity was greater in the upper portion of the AAIW at $800 \mathrm{~m}$ than at $600 \mathrm{~m}$ (Fig. 3). At Stn 1, bacterial productivities were high and doubling times short in the colder waters below the salinity minimum. In these zones of high bacterial productivity in the AAIW, the productivity was about 3 to $5 \mu \mathrm{g} \mathrm{C} \mathrm{m}{ }^{-3} \mathrm{~d}^{-1}$ and the integrated productivity would be about $1 \mathrm{mg} C$ $\mathrm{m}^{-2} \mathrm{~d}^{-1}$ in a water column $300 \mathrm{~m}$ thick. In the upper mixed layer at this station, the integrated productivity was about $90 \mathrm{mg} \mathrm{C} \mathrm{m} \mathrm{m}^{-2} \mathrm{~d}^{-1}$. At Stn 2 , bacterial productivities were very low at 400 to $700 \mathrm{~m}$, then increased significantly $(p<0.01)$ at $800 \mathrm{~m}$ and just below the salinity minimum at $1200 \mathrm{~m}$ (Fig. 3). The values were about $8 \mu \mathrm{g} \mathrm{C} \mathrm{m}^{-3} \mathrm{~d}^{-1}$, whereas at $1500 \mathrm{~m}$ the productivity was only 0.4 .

DNA accounted for 40 to $70 \%$ of tritium incorporated into macromolecules; thus it was necessary to separate labelled DNA from other macromolecules on the filters (Table 1). Bacterial population densities were always greater in the upper mixed layer than in deeper waters, and were greatest in surface waters in summer south of Tasmania (Tables 1, $2 \& 3$ ).

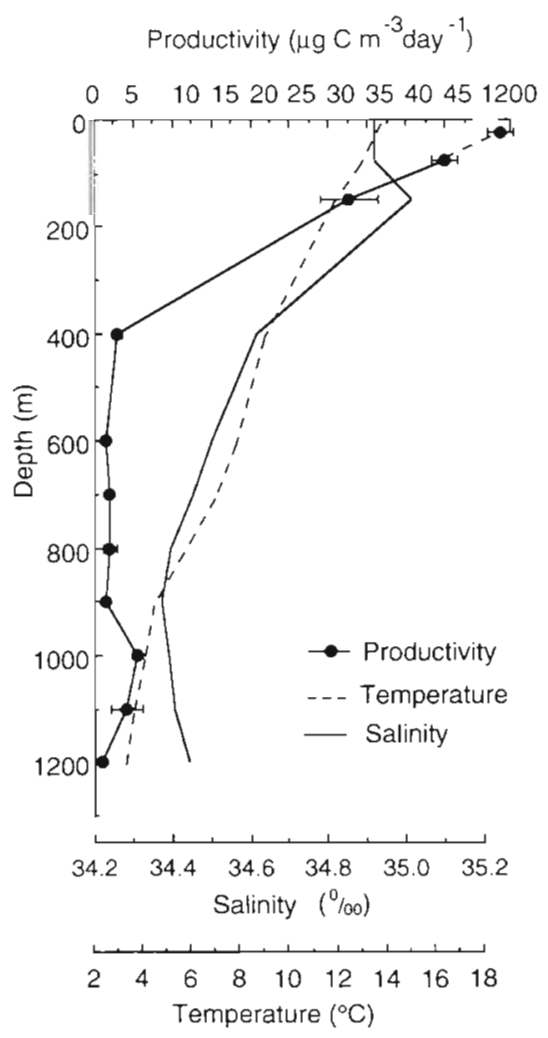

Fig. 2. Depth profiles of bacterial productivity, salinity and temperature in the water column in February 1992 at $\operatorname{Stn} 1$ on the southern continental margin $\left(44^{\circ} 42.9^{\prime} \mathrm{S}, 145^{\circ} 58.05^{\prime} \mathrm{E}\right.$; bottom depth $2789 \mathrm{~m}$ ). Standard error bars for productivity ( $\mathrm{n}$ $=4$ ) are shown, except where less than the size of the symbol

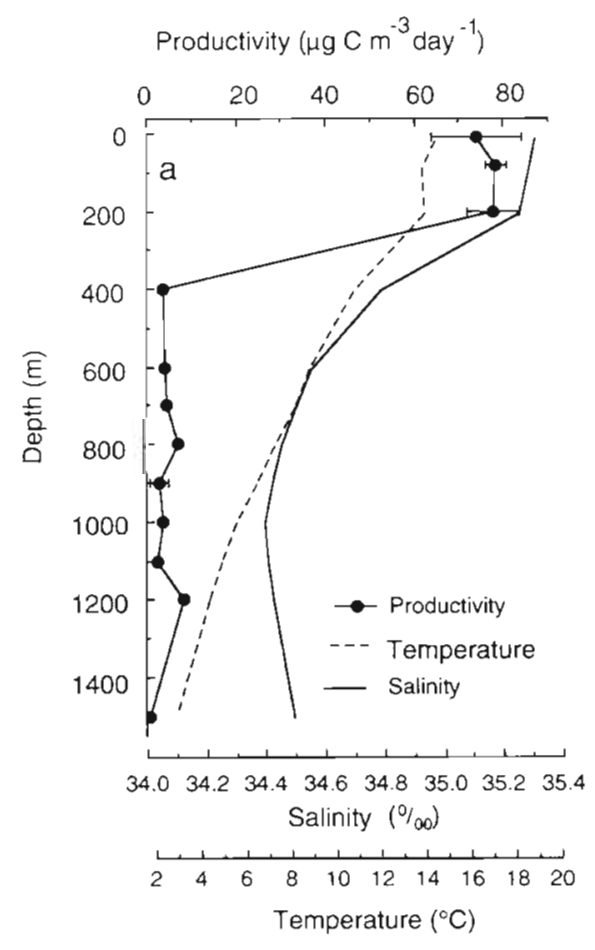

Fig. 3. Depth profiles of bacterial doubling times, productivity, salinity and temperature in the water column in July 1991 at Stn $2\left(41^{\circ} 14.2^{\prime} \mathrm{S}, 148^{\circ} 56.37^{\prime} \mathrm{E}_{\text {; }}\right.$ bottom depth $\left.1888 \mathrm{~m}\right)$. Standard error bars as in Fig. 2

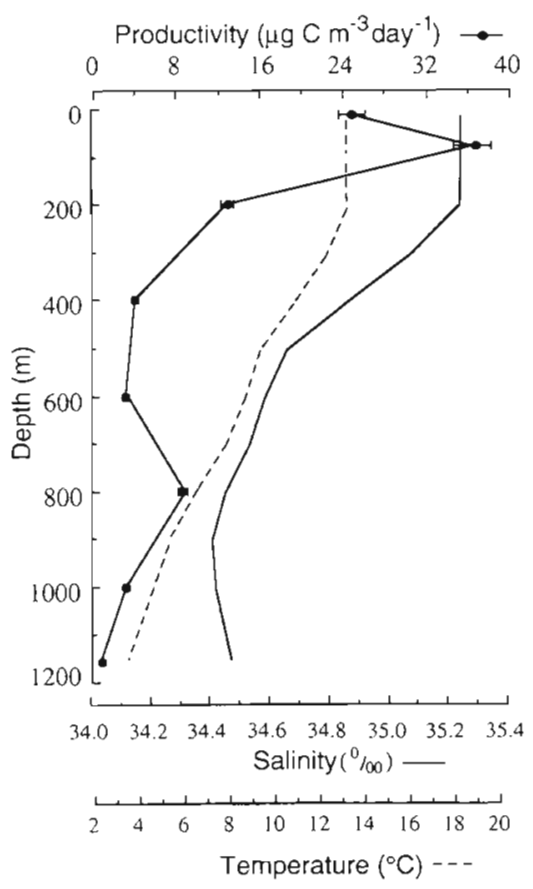

Fig, 4 Depth profile of temperature, salinity and bacterial productivity at $S \operatorname{tn} 3\left(41^{\circ} 15.16^{\prime} S, 148^{\circ} 48.06^{\prime} \mathrm{E}\right.$; bottom depth $1225 \mathrm{~m})$. Standard error bars for productivity $(\mathrm{n}=4)$ ) are shown, except where less than the size of the symbol 
Table 1. Numbers of bacteria and bacterial doubling times and cell division rates in water, percent bacterial growth on particles and labelled DNA as a percentage of total labelled macromolecules in July at Stn 2, Tasman Sea (see Fig. 3). Means \pm 1 SE are shown; $\mathrm{n}=12$ for numbers, $\mathrm{n}=4$ for division rate. Within-sample variation in rates of DNA synthesis was 2 to $5 \%$ at each depth nd: not determined

\begin{tabular}{|c|c|c|c|c|c|c|}
\hline \multirow[t]{2}{*}{$\begin{array}{l}\text { Depth } \\
\text { (m) }\end{array}$} & \multirow[t]{2}{*}{$\begin{array}{l}\text { Total number } \\
\left(\times 10^{11} \mathrm{~m}^{-3}\right)\end{array}$} & \multirow[t]{2}{*}{$\begin{array}{l}\text { Doubling } \\
\text { time (mo) }\end{array}$} & \multicolumn{2}{|c|}{$\begin{array}{l}\text { Bacterial division rate } \\
\text { (no. cells dividing } \times 10^{4} \mathrm{~m}^{-3} \mathrm{~h}^{-1} \text { ) }\end{array}$} & \multirow{2}{*}{$\begin{array}{c}\text { Dividing bacteria } \\
\text { on particles } \\
(\%)\end{array}$} & \multirow[t]{2}{*}{$\begin{array}{l}\text { DNA } \\
(\%)\end{array}$} \\
\hline & & & Total & On particles & & \\
\hline 10 & $3.24 \pm 0.30$ & 2 & $12.9 \pm 1.5$ & $2.75 \pm 0.11$ & 21 & 54 \\
\hline 80 & $2.43 \pm 0.07$ & 1 & $13.6 \pm 0.3$ & $2.21 \pm 0.02$ & 16 & 50 \\
\hline 200 & $2.10 \pm 0.04$ & 1 & $13.5 \pm 0.9$ & $3.97 \pm 0.88$ & 3 & 46 \\
\hline 400 & $1.03 \pm 0.008$ & 11 & $0.7 \pm 0.08$ & $0.23 \pm 0.05$ & 34 & 38 \\
\hline 600 & $0.55 \pm 0.003$ & 5 & $0.7 \pm 0.09$ & $0.26 \pm 0.02$ & 36 & 60 \\
\hline 700 & Sample Iost & & $0.8 \pm 0.11$ & $0.23 \pm 0.04$ & 29 & 53 \\
\hline 800 & $0.29 \pm 0.001$ & 2 & $1.2 \pm 0.08$ & $0.65 \pm 0.04$ & 52 & 59 \\
\hline 900 & $0.25 \pm 0.004$ & 4 & $0.5 \pm 0.29$ & $0.21 \pm 0.06$ & 42 & 54 \\
\hline 1000 & $0.21 \pm 0.007$ & 3 & $0.6 \pm 0.06$ & $0.18 \pm 0.02$ & 29 & 44 \\
\hline 1200 & $0.18 \pm 0.008$ & 1 & $0.5 \pm 0.002$ & & nd & 58 \\
\hline 1500 & $0.12 \pm 0.005$ & 7 & $0.15 \pm 0.005$ & & nd & 74 \\
\hline
\end{tabular}

The doubling times for the populations varied between water masses; it was fast in surface layers and very slow below the mixed layer around $400 \mathrm{~m}$ depth. Doubling times of the bacterial populations in the AAIW were faster than in waters immediately above or below (Tables 1, 2 \& 3). At Stn 1, doubling times were just as fast $(1 \mathrm{mo})$ in the lower portion of the AAIW water mass as those of bacteria in the surface water; they were also significantly faster in the water mass at $800 \mathrm{~m}$ than at $600 \mathrm{~m}(\mathrm{p}=0.01)$.

In the east coast waters, many bacteria were observed by epifluorescence microscopy to be attached to particles of around 20 to $50 \mu \mathrm{m}$ diameter. A considerable portion of the bacterial production occurred on particles in the deeper layers, although immediately below the photic zone at $200 \mathrm{~m}$, only $3 \%$

Table 2. Numbers of bacteria, doubling times and percent of bacterial growth on particles in water at Stn 1 (see Fig. 2) south of the continental margin of Tasmania in February 1992. Standard errors $(n=12)$ of bacterial numbers are shown

\begin{tabular}{|rccc|}
\hline $\begin{array}{c}\text { Depth } \\
(\mathrm{m})\end{array}$ & $\begin{array}{c}\text { Number } \\
\left(\times 10^{11} \mathrm{~m}^{-3}\right)\end{array}$ & $\begin{array}{c}\text { Doubling time } \\
(\mathrm{mo})\end{array}$ & $\begin{array}{c}\text { Bacterial growth } \\
\text { on particles }(\%)\end{array}$ \\
\hline 1 & $11.3 \pm 0.9$ & 0.5 & 1 \\
75 & $3.69 \pm 0.16$ & 4 & 10 \\
150 & $2.12 \pm 0.54$ & 3 & 10 \\
400 & $0.60 \pm 0.89$ & 9 & $<7$ \\
600 & $0.59 \pm 0.03$ & 19 & 70 \\
700 & $0.50 \pm 0.02$ & 12 & $<2$ \\
800 & $0.41 \pm 0.01$ & 9 & 40 \\
900 & $0.40 \pm 0.02$ & 13 & $<10$ \\
1000 & $0.28 \pm 0.01$ & 2.6 & $<2$ \\
1100 & $0.35 \pm 0.02$ & 4 & 3 \\
1200 & $0.31 \pm 0.03$ & 17 & $<2$ \\
\hline
\end{tabular}

of growing bacteria were attached to particles (Table 1). At the southern station, however, less bacterial growth was associated with particles, except at depths of 600 and $800 \mathrm{~m}$, where significantly $(p=0.05)$ large proportions of growing bacteria were on particles (Table 2)

\section{DISCUSSION}

The exponential decrease in bacterial productivity with depth to $400 \mathrm{~m}$ is expected if the source of organic matter for the bacterial growth were particles sinking from the photic zone (Cho \& Azam 1988, Karl 1988). However, bacterial productivities and growth rates were greater in the AAIW than in the water masses above at 400 to $600 \mathrm{~m}$. This indicates that there was a large pool of labile organic matter being oxidised by bacteria in these subantarctic water masses. The most likely mechanism that would explain its origin or

Table 3. Numbers of bacteria and doubling times in July at Str 3, east of Tasmania (see Fig. 4). Standard errors of bacterial numbers are shown

\begin{tabular}{|ccc|}
\hline $\begin{array}{c}\text { Depth } \\
(\mathrm{m})\end{array}$ & $\begin{array}{c}\text { Total number } \\
\left(\times 10^{11} \mathrm{~m}^{-3}\right)\end{array}$ & $\begin{array}{c}\text { Doubling time } \\
(\mathrm{mo})\end{array}$ \\
\hline 10 & $1.51 \pm 0.07$ & 3 \\
80 & $1.14 \pm 0.04$ & 2 \\
200 & $1.09 \pm 0.01$ & 5 \\
400 & $0.54 \pm 0.006$ & 7 \\
600 & $1.09 \pm 0.009$ & 18 \\
800 & $0.42 \pm 0.002$ & 3 \\
1000 & $0.03 \pm 0.001$ & 6 \\
1200 & $0.03 \pm 0.001$ & 18 \\
\hline
\end{tabular}


source is that the organic matter was sinking with water masses at a convergence zone to the south, i.e. in the subtropical and subantarctic frontal zones. The highest bacterial growth rate occurred in the water mass below the salinity minimum, which probably originated a little south of the subantarctic front. Similar high rates of bacterial growth in the AAIW have been observed just north of the subantarctic and subtropical frontal zone in the Indian Ocean (Moriarty \& Bianchi 1994).

Our values for bacterial production are mostly lower than those reported recently for the northern Pacific by Cho \& Azam (1988), who used similar techniques and conversion factors. Their values for the upper mixed layer were around 1 to $10 \mathrm{mg} \mathrm{C} \mathrm{m}{ }^{-3} \mathrm{~d}^{-1}$ compared to 0.03 to $1.2 \mathrm{mg} \mathrm{C} \mathrm{m}^{-3} \mathrm{~d}^{-1}$ in the Tasman Sea; at $400 \mathrm{~m}$ depth, their values were 10 to $30 \mu \mathrm{g} \mathrm{C} \mathrm{m} \mathrm{m}^{-3} \mathrm{~d}^{-1}$, whereas in the Tasman we found values of 2 to $3 \mu \mathrm{g} \mathrm{C}$ $\mathrm{m}^{-3} \mathrm{~d}^{-1}$

Bacterial production, which is calculated from growth rates determined from the rates of DNA synthesis, is a measure of the carbon flux through bacteria. The growth efficiency must be determined for an accurate estimate of total carbon flux through bacteria, but this is difficult to measure in situ. Efficiencies varying from $<10 \%$ to over $50 \%$ have been reported (Payne \& Weibe 1978, Moriarty 1987). In a closed system, carbon flux equals bacterial productivity when the growth efficiency is $50 \%$, whereas carbon flux is twice the productivity in an open system, i.e. where there is no recycling of carbon (Moriarty 1989). If nitrogen or other nutrients are scarce, growth efficiency would be lower, and more organic carbon may be converted to extracellular polysaccharides, which are not included in biomass determinations. Thus the values for bacterial production give minimum values for rates of organic matter cycling through the bacteria. In considering the water column ecosystem to be an open one, we estimate carbon flux to be twice the values for bacterial productivity, and the values for oxygen consumption (calculated from carbon respiration assuming a respiratory quotient, $R Q$, of 1 ) to be equivalent to productivity. A good correspondence has been found for carbon oxidation rates in continental margin sediments at depths of 400 to $1000 \mathrm{~m}$ calculated both from rates of DNA synthesis in bacteria and rates of oxygen consumption determined from oxygen concentration gradients (Moriarty et al. 1991).

In the AAIW, we estimate carbon oxidation rates to be 6 to $16 \mu \mathrm{g} \mathrm{C} \mathrm{m}^{-3} \mathrm{~d}^{-1}$, and oxygen utilisation rates to be 16 to $42 \mu \mathrm{g} \mathrm{O} \mathrm{m}^{-3} \mathrm{~d}^{-1}$ ( 2 to $5 \mathrm{ml} \mathrm{O}_{2} \mathrm{~m}^{-3} \mathrm{yr}^{-1)}$. In the deep water at $1500 \mathrm{~m}$, carbon flux through bacteria is about $0.9 \mu \mathrm{g} \mathrm{C} \mathrm{m}^{-3} \mathrm{~d}^{-1}$ and oxygen utilisation would be only $0.6 \mu \mathrm{m} \mathrm{m}^{-3} \mathrm{yr}^{-1}$. These values for bacterial production and oxygen utilisation are an order of magnitude lower than those of Sorokin's (Sorokin 1978, Sorokin et al. 1985).

Sorokin used a method for determining bacterial production based on the incorporation of ${ }^{14} \mathrm{CO}_{2}$ into organic matter in the dark, but this procedure does not give accurate results, because there is not a direct relationship between the various biochemical and physiological processes leading to $\mathrm{CO}_{2}$ fixation and cell division. Although his actual values were too high, our results indicate that he was correct in concluding that bacterial activity and the pool of labile organic matter in intermediate waters was substantially more than that likely to be due to vertical sedimentation of organic matter. He suggested that the organic matter was only slowly mineralised in transit because the water temperature was low, until it reached the warmer tropical regions and moved towards the surface or mixed with warmer water en route (Sorokin 1978). Bacterial metabolic activity could have been low not only because the temperature of the AAIW was low, but because the bacteria may have been inhibited by the increase in pressure after sinking to depths of about 1000 to $1200 \mathrm{~m}$ at the frontal zone. Bianchi \& Garcin (1993) noted that when surface bacteria in the Mediterranean Sea were compressed to a pressure equivalent to a depth of $1100 \mathrm{~m}$, rates of metabolic activity decreased considerably. We did not have a pressure vessel, but clearly more research is needed with pressure control of the type used by Bianchi \& Garcin (1993).

The doubling times in the AAIW were comparable to those in the surface waters in winter (Table 1). The similar population density but faster doubling times of the bacteria in the AAIW compared to overlying water indicate that grazing animals were feeding on the bacteria at a greater rate in the AAIW. A high abundance of flagellates was associated with the bacterial activity in similar water masses in the Indian Ocean (Sorokin et al. 1985). The bacterial productivity in the intermediate waters indicates that mineralisation of organic matter to carbon dioxide and inorganic nutrients occurs as these water masses move from the formation region. Thus budgets and models of carbon cycling in the Southern Ocean will need to take into account this lateral advection of primary production, if further work shows it to be substantial.

Most growing bacteria in the oceanic water columns have been reported to be living freely and not attached to particles (Cho \& Azam 1988). The high proportion of growing bacteria attached to particulate material in many of the samples at the east coast stations is in contrast with such data from the northern oceans, but is in agreement with observations made by Sorokin in the Central Pacific who reported 20 to $30 \%$ of bacteria on aggregates. There is a high concentration of organic 
matter that binds copper in these waters, especially in the AAIW it was interpreted as a biological phenomenon associated with organic matter derived from the Antarctic (Mackey 1986). As extracellular polysaccharides from bacteria bind copper strongly, they could be the copper-binding ligands observed by Mackey (1986). Fine material that appeared to be slime or mucus was observed under the microscope, and many bacteria were embedded in it. It is possible that the slime was derived from faecal matter or slime produced by animals in the water column, as deep-scattering layers were prominent in the waters off the east coast of Tasmania.

The differences in rates of bacterial production with depth at the different stations indicate different spatial and temporal origins of the water masses, e.g. at $\operatorname{Stn} 2$, productivities were greater at 800 and $1200 \mathrm{~m}$ than at 600 or $1100 \mathrm{~m}$ (Fig. 3). The origin of the AAIW in the Pacific Ocean is not well understood, but it has been suggested recently that it is formed mainly west of South America and then some of it moves west in the subtropical gyre; this meets older AAIW that is advected from other formation sites to the west (Tomczak \& Godfrey 1994). In the Tasman Sea, the westward-moving water enters from the north and it meets AAIW with a minimum salinity of $<34.4 \%$ entering from the south. Variations in bacterial productivity in the AAIW may indicate different origins (reflecting seasonal or spatial variations in primary production and bacterial communities dependent on it) and age of the water mass in the AAIW. Older water masses would have less bacterial activity due to exhaustion of labile organic matter for bacterial growth. There is greater bacterial productivity in the colder water below the salinity minimum than in the water at the salinity minimum (Figs. 2 \& 3 ). This greater productivity indicates substantially greater availability of labile organic matter than at the core of the AAIW. This suggests that the core of the AAIW mass is older than that at the lower boundary and, thus, that the deeper water with greater bacterial productivity has been subducted at or near the Polar Front closer to the Tasman Sea than the rest of the AAIW.

Sorokin's suggestion that there is a pool of organic matter moving under the upper layers of the oceans from the Antarctic to the tropics is substantiated by the data reported here, although more detailed experiments and sampling stations are needed to delineate the extent to which organic matter is advected. Further support for his hypothesis is provided by 2 other studies. Firstly, Wangersky (1976) reported higher concentrations of particulate organic carbon in AAIW all the way from the Southern Ocean to the Equator. Secondly, the water in the Peruvian upwelling originates in the Equatorial Undercurrent and this is derived from
Subantarctic Mode Water (SAMW), which originates from surface waters between the Subtropical Convergence and the Polar Front in the Antarctic (Toggweiler et al. 1991). Evidence for this is given by the low ratio of ${ }^{14} \mathrm{C}:{ }^{12} \mathrm{C}$ in the waters of the Peruvian upwelling and the SAMW We would predict that bacterial productivity, and thus the availability of organic carbon to heterotrophic bacteria, would be greater in the SAMW than in surrounding water masses, because of the recent surface origin of SAMW. It is possible that the relatively high values for bacterial activity reported by Sorokin in the Pacific related to SAMW, as the temperatures and depths at which he found greater activity were above those where AAIW would be expected. Bacterial productivity is higher in mode waters of the Indian Ocean than in water masses above or below (Moriarty \& Bianchi 1994). The bacterial growth rates would be influenced by the proportions of bacterial populations mixed from recent and old water and also by any organic matter derived from vertically sinking particles.

The results reported here are only from a preliminary study, as the cruises were not planned around these experiments. The results demonstrate, however, that further studies of bacterial productivity in both the AAIW and mode waters on a wider time and spatial scale would be profitable. A series of measurements could help determine rates of water mass movement from seasonal or spatial variation in bacterial growth rates and species composition, because these would depend on the amount and nature of the organic matter being mineralised and the period of time since the water was subducted. A study of the bacterial community structure and productivity in vertical profiles from the subantarctic to the Equator would be complementary to physical and chemical data in delineating water mass origins and possibly rates of movement if seasonal signatures are apparent. The paradigm that all organic carbon is either recycled in the photic zone or sinks vertically has to be changed to include the scenario, at least in the southern oceans, that labile organic carbon is advected horizontally for long distances and perhaps long time scales.

Acknowledgements. We thank Dr Y. I. Sorokin for stimulating us to undertake this study. We thank Dr A. Koslow for his invitation to participate in the work on FRV 'Southern Surveyor' and his collaboration. We also thank Dr S. Rintoul for many helpful discussions. Drs D. J. Mackey, J. Parslow and S. Rintoul kindly made helpful comments on the manuscript.

\section{LITERATURE CITED}

Banse, K. (1974). On the role of bacterioplankton in the tropical ocean. Mar. Biol. 24: 1-5

Bianchi, A., Garcin, J. (1993). In stratified waters the meta- 
bolic rate of deep-sea bacteria decreases with decompression. Deep Sea Res. 40: 1703-1710

Cho, B. C., Azam, F. (1988). Major role of bacteria in biogeochemical fluxes in the ocean's interior. Nature 332: $441-443$

Karl, D. M. (1988). Downward flux of particulate organic matter in the ocean: a particle decomposition paradox. Nature 332: 438-441

Lee, S., Fuhrman, J. A. (1987). Relationship between biovolume and biomass of naturally derived marine bacterioplankton. Appl. environ. Microbiol. 53: 1298-1303

Longhurst, A. R. (1991). Role of the marine biosphere in the global carbon cycle. Limnol. Oceanogr. 36: 1507-1526

Mackey, D. J. (1986). Copper-complexing capacity of south Pacific waters. Austr. J. mar. Freshwat. Res. 37: 437-450

Moriarty, D. J. W. (1987). Methodology for determining biomass and productivity of microorganisms in detrital food webs. In: Moriarty, D. J. W., Pullin, R. S. V. (eds.) Detritus and microbial ecology in aquaculture. International Centre for Living Aquatic Resources Management, Manila, p. $4-31$

Moriarty, D. J. W. (1988). Accurate conversion factors for calculating bacterial growth rates from thymidine incorporation into DNA: elusive or illusive? Arch. Hydrobiol. Beih. Ergeb. Limnol. 31. $211-217$

Moriarty, D. J. W. (1989). Relationships of bacterial biomass and production to primary production in marine sediments. In: Hattori, T., Ishida, Y., Maruyama, Y., Morita, R. Y., Uchida, A. (eds.) Recent advances in microbial ecology. Japan Scientific Societies Press, Tokyo, p. 349-354

Moriarty, D. J. W. (1990). Techniques for estimating bacterial growth rates and production of biomass in aquatic environments. In: Grigorova, R., Norris, J. R. (eds.) Methods in microbiology. Academic Press, London, p. 211-234

Moriarty, D. J. W., Bianchi, M. (1994). Bacterial production and advection of organic carbon from the Southern Ocean in water at intermediate depths. EOS 75: 199

Moriarty, D. J. W., Skyring, G. W., O'Brien, G. W., Heggie,

This article was submitted to the editor
D. T (1991). Heterotrophic bacterial activity and growth rates in sediments of the continental margin of eastern Australia. Deep Sea Res. 38: 693-712

Packard, T. T (1985). Measurement of electron transport acitivity of microplankton. In: Jannasch, H. W., Williams, P. J. L. (eds.) Advances in aquatic microbiology. Academic Press, London, p. 207-261

Payne, W. J., Weibe, W. J. (1978). Growth yield and efficiency in chemosynthetic organisms. A. Rev. Microbiol. 32: $155-183$

Riemann, B., Bjørnsen, P. K., Newell, S., Fallon, R. (1987). Calculation of cell production of coastal marine bacteria based on measured incorporation of ${ }^{3} \mathrm{H}$-thymidine. Limnol. Oceanogr. 32: 471-476

Sorokin, Y. I. (1971). On the role of bacteria in the productivity of tropical oceanic waters. Int. Revue ges. Hydrobiol. 56: $1-48$

Sorokin, Y. I. (1973). Data on the biological productivity of the western tropical Pacific Ocean. Mar. Biol. 20: 177-196

Sorokin, Y. I. (1977). Productivity and the trophic role of bacterioplankton in the region of equatorial divergence. Pol. Arch. Hydrobiol. 24: 241-259

Sorokin, Y. 1. (1978). Decomposition of organic matter and nutrient regeneration. In: Kinne, O. (ed.) Marine ecology. Wiley, Chichester, p. 501-616

Sorokin, Y. I., Kopylov, A. I., Mamaeva, N. V. (1985). Abundance and dynamics of microplankton in the central tropical Indian Ocean. Mar. Ecol. Prog. Ser. 24: $27-41$

Suess, E. (1980). Particulate organic carbon flux in the oceans - surface productivity and oxygen utilisation. Nature 288 : $260-263$

Toggweiler, J. R., Dixon, K., Broecker, W. S. (1991). The Peru upwelling and the ventilation of the South Pacific thermocline. J. geophys. Res. 96: 20467-20497

Tomczak, M., Godfrey, J S. (1994). Regional oceanography: an introduction. Pergamon Press, Oxford

Wangersky, P. J. (1976). Particulate organic carbon in the Atlantic and Pacific oceans. Deep Sea Res. 23: 457-464

Manuscript first received: June 20,1994

Revised version accepted: October 18, 1994 